\title{
Path Analysis on Factors Associated withthe Incidence of Diarrhea in Infants Aged 6-12 MonthsatKaranganyar Community Health Center,inPurbalingga, Indonesia
}

\author{
Norma Arista Narzah'), Pawito's), Ruben Dharmawan3) \\ ${ }^{1)}$ Community Health Center of Karanganyar, Purbalingga, Indonesia \\ 2)Faculty of Social and Communication, SebelasMaret University, Surakarta \\ 3)Faculty of Medicine, SebelasMaret University
}

\begin{abstract}
Background: A diarrheal disease is an endemic disease and has outbreak potential in Indonesia. In Indonesia (2012) the number of pain diarrhea on toddler reached 900 per 1,000 inhabitants. This study aimed to determine the factors associated to the incidence of diarrhea in infant aged 612 months.

Subjects and Method: This was an observational analytic study with cross sectional design. This was conducted in Karanganyar Community Health Center, Purbalingga, Indonesia, in April-Mei 2016. A total of 100 subjects was selected Fixed Disease. The data was using the questionnaire. The data analysis used path analysis.

Results: There was a direct correlation between breast feeding, nutritional status, personal hygiene of mothers and infants, and the availability of basic sanitation with the incidence of diarrhea, and statistically significant $(b=2.62 ; 95 \% \mathrm{CI}=1.00$ to $4.24 ; \mathrm{p}=0.001),(\mathrm{b}=3.37 ; 95 \% \mathrm{CI}$ $=0.61$ to $6.12 ; \mathrm{p}=0.017),(\mathrm{b}=3.70 ; 95 \% \mathrm{CI}=2.07$ to $5.33 ; \mathrm{p}<0.001),(\mathrm{b}=3.00 ; 95 \% \mathrm{CI}=0.69$ to 5.32 ; $\mathrm{p}=0.011)$. There is a positive correlation between indirect breast feeding with the incidence of diarrhea through nutritional status, culture with the incidence of diarrhea through breast feeding, culture with the incidence of diarrhea through the facility's individual mothers and babies, the availability of basic sanitation with diarrhea through individual facility's mothers and babies, statistically significant $(\mathrm{b}=0.91 ; 95 \% \mathrm{CI}=-0.28$ to2.11; $\mathrm{p}=0.135),(\mathrm{b}=1.83 ; 95 \% \mathrm{CI}=0.95$ to 2.22; $\mathrm{p}<0.001),(b=1.40 ; 95 \% \mathrm{CI}=0.46$ to $2.25 ; \mathrm{p}=0.003),(\mathrm{b}=1.10 ; 95 \% \mathrm{CI}=-0.10$ to $2.22 ; \mathrm{p}=0.076)$.

Conclusion: There is a direct correlation between breast feeding, nutritional status, personal hygiene of mothers and infants, and the availability of basic sanitation with the incidence of diarrhea. There is indirect correlation between breast milk with the incidence of diarrhea through nutritional status, culture, personal of mother and infants, the availability of basic sanitation with diarrhea through individual facility's mother and the baby.
\end{abstract}

Keywords: nutritional status, culture, human breast milk, sanitation, individual hygiene, diarrhea

\section{Correspondence:}

Norma Arista Narzah.Community Health Center, Karanganyar, Purbalingga, Indonesia.

Email: normaaristanarzah@yahoo.com.

\begin{tabular}{l} 
BACKGROUND \\
\hline Diarrhea is still a world health problem and \\
is one of a number of infectious diseases \\
with pain and death are still relatively high. \\
Diarrhea one contributor number of pain \\
and death of children in various countries \\
including Indonesia. Indonesia is a country
\end{tabular}

with Extraordinary potential Genesis (of the outbreak) diarrheal disease.

Several factors that increase the risk of diarrhea that is the lack of clean water, disposal of feces, preparation and storage of food that is not worth it.bPrevention of diarrhea that is keeping the environment clean, personal hygiene, breast feeding and nutrition (Tatik, 2011). 
The proportion of households that have access to a source of clean drinking water in Indonesia still $66.8 \%$. The proportion of households in Indonesia use its own chapter is $76.2 \%, 6.7 \%$, the Commons and public facilities of $4.2 \%$. Household waste water shelter in Indonesia dumped directly into got $46.7 \%$. Only $15.5 \%$ who use the shelter closed yard with furnished SPAL and $13.2 \%$ use an open shelter in the courtyard. In terms of waste management RT only $24.9 \%$ carried by officers (Riskesdas Indonesia, 2013).

The results of the 2007 Riskesdas, the number one cause of death for diarrhea in infants (31.4\%) and toddlers (25.29\%). Infant mortality by 2014 of 23.00/1.00 live birthsand in Central Java by 2014 of 10.08/1.00o live births (Health profile of Indonesia, 2014).

In 2013 occurred 8 outbreak of diarrhea, the number of sufferers of 646 people, the death of 7 people (CFR 1.08\%), 20146 outbreak of diarrhea occurs, the number of sufferers of 2.549 people and the deaths of 29 people $1.14 \%$ (Health profile of Indonesia, 2014).

Cases of diarrhoea in Central Java by 2014 of 79.8\%. Causes of diarrhea include risksrelated to clean water facility, serving food, and a clean and healthy living behaviours(Health Profile of Central Java, 2014).

Infant mortality (AKB) Purbalingga 2014 of $11.00 \%$ (162) cases per 1.000 live births.Trends in infant mortality in the last 3 years tends to rise, namely the year 2012 of $10.89 \%, 11.31 \%$, 2013 and $201411.00 \%$. The number of deaths of babies caused casesof diarrhea tend to experience increased from the year 2012 i.e. 2 babies, infants,2013 (5 infants), 2014 (5 infants) (Health profile of Purbalingga, 2014).

Karanganyar is clinics clinics located in Purbalingga. The case of the death of a
babyinKaranganyar Clinics in 2012, namely 11 cases, the year 201310 cases, and 2014 4 cases. In 2014 to happen 1 infant mortality due to diarrhea.Cases of diarrhoea in infants who handled Clinics Karanganyar in 2014 IE the number of 149 babies 19.03\% (Health Profile of clinics Karanganyar 2014).

You can prevent diarrheal diseases or reduced by means of maintaining hygiene and healthy life patterns. From the above statement researchers interested in knowingthe Path Analysis of the factors related to the incidence of diarrhoea in infants (612 months) in the working area Clinics Karanganyar, Purbalingga.

\begin{tabular}{l}
\hline SUBJECTS AND METHOD \\
\hline This was an observational analytic \\
withcross sectional design. A total of 100 \\
subjects were selected by fixeddisease \\
sampling. Exogenous variables in the study \\
of nutritional status, culture, breast feed- \\
ing. Endogenous variables were personnel \\
mothers and babies, the availability of basic \\
sanitation, the incidence of diarrhea. The \\
data was collected with a questionnaire and \\
analyzed using path analysis.
\end{tabular}

\section{RESULTS}

The characteristics of study subjects are gender and age. The category of gender were $43.0 \%$ male, and $35.4 \%$ women. Most study subjects were age 10 months (20.0\%) and age 6 months (11.0\%).

Multivariateanalysis describes the relationship of more than one variable. Exogenous variables were breastfeeding, nutritional status, and culture. Endogenous variables wereindividual mother and baby hygiene, availability of basic sanitation, the incidence of diarrhea. The method used is the path analysis using STATA program 13. 


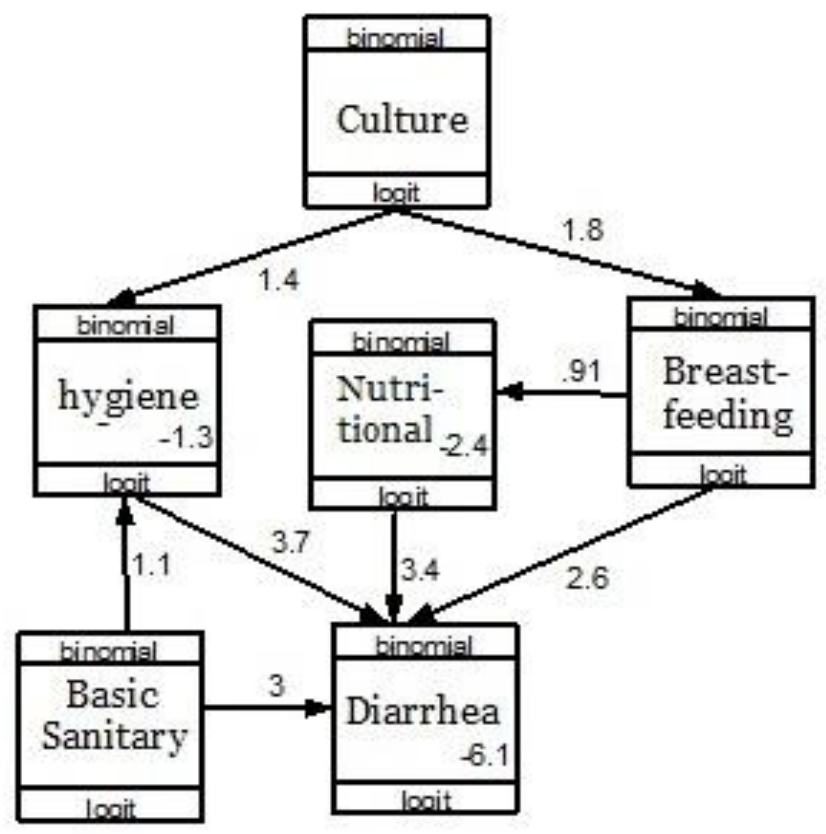

Picture 1. Path analysis: association of culture, nutrition status, breastfeeding, basic sanitary, maternal hygiene and infant with the incidence of diarrhea

Tabel 1. Result of path analysis: association of culture, nutrition status, breastfeeding, basic sanitary, maternal hygiene and infant with the incidence of diarrhea

\begin{tabular}{|c|c|c|c|c|c|c|}
\hline \multirow{2}{*}{$\begin{array}{l}\text { Dependent } \\
\text { Variables }\end{array}$} & & \multirow{2}{*}{$\begin{array}{c}\text { Independent } \\
\text { variables }\end{array}$} & \multirow{2}{*}{ b } & \multicolumn{2}{|c|}{ 95\% CI } & \multirow[b]{2}{*}{$\mathbf{p}$} \\
\hline & & & & Lower & Upper & \\
\hline \multicolumn{7}{|l|}{ Direct Effect } \\
\hline \multirow[t]{4}{*}{ Diarrhea } & $\leftarrow$ & Hygiene & 3.70 & 2.07 & $5 \cdot 33$ & $<0.001$ \\
\hline & $\leftarrow$ & Nutrition Status & 3.37 & 0.61 & 6.12 & 0.017 \\
\hline & $\leftarrow$ & Breast Feeding & 2.62 & 1.00 & 4.24 & 0.001 \\
\hline & $\leftarrow$ & Basic Sanitary & 3.00 & 0.69 & $5 \cdot 32$ & 0.011 \\
\hline \multicolumn{7}{|l|}{ Indirect Effect } \\
\hline Nutrition Status & $\leftarrow$ & Breast Feeding & 0.91 & -0.28 & 2.11 & 0.135 \\
\hline Breast Feeding & $\leftarrow$ & Culture & 1.83 & 0.95 & 2.71 & $<0.001$ \\
\hline Hygiene & $\leftarrow$ & Culture & 1.36 & 0.46 & -2.25 & 0.003 \\
\hline Hygiene & $\leftarrow$ & Basic Sanitary & 1.05 & -0.10 & 2.22 & 0.076 \\
\hline
\end{tabular}

\section{DISCUSSION}

There is a direct positive relationship between breastfeeding $(\mathrm{b}=2.62 ; 95 \% \mathrm{CI}=$ 1.00 to $4.24 ; \mathrm{p}=0.001$ ), nutritional status $(\mathrm{b}=3.37 ; 95 \% \mathrm{CI}=0.61$ to $6.12 ; \mathrm{p}=0.017)$, individual hygiene of mothers and infants $(b=3.70$; CI $95 \%=2.07$ to $5.33 ; p<0.001)$, and the availability of basic sanitation $(b=$ 3.00; $95 \% \mathrm{CI}=0.69$ to $5.32 ; \mathrm{p}=0.011$ ) with the incidence of diarrhea and statistically significant.

There is a positive relationship and statistically significant between indirect breast feeding with the incidence of diarrhoea through nutritional status $(\mathrm{b}=$ $0.91 ; 95 \% \mathrm{CI}=-0.28$ to $2.11 ; \mathrm{p}=0.135$ ), culture with the incidence of diarrhea through breastfeeding $(b=1.83 ; 95 \% \mathrm{CI}=$ 0.95 to $2.22 ; \mathrm{p}<0.001$ ), culture with the incidence of diarrhea through the facility's individual mothers and babies $(b=1.40 ; 95 \%$ $\mathrm{CI}=0.46$ to $2.25 ; \mathrm{p}=0.003$ ), the availability of basic sanitation with diarrhea through individual facility's mothers and babies $(b=1.10 ; 95 \% \mathrm{CI}=-0.10$ to $2.22 ; \mathrm{p}=0.076$ ).

Breast feeding is the main food given to newborn babies without being given extra food (WHO, 2001). Exclusive breast 
feeding is baby age 0-6 months only given breast feeding alone without providing additional food or beverage (Proverawati and Rahmawati, 2012).

Colostrum can provide protection because it contains primary source of secretory IgA (SigA) and provide protection against infection gastrointestinal (Bahiyatun, 2009).

Breast feeding can protect the occurrence of diarrhea with intestinal mucosa covered and was able to kill pathogens cause infection (Salone, 2013). Infection can come from a bottle, pacifier, milk, baby food and are not given breast feeding exclusively. Granting of breast feeding during the first 6 months of life were able to lower the mortality and morbidity of diarrhea (Helayel et al., 2009).

According to Rahmadhani et al., (2013) are obtained as a result of a statistical test of Chi-Square $=0.001 \mathrm{p}$ rated and this significant results $(\mathrm{p}<0.5)$. Exclusive breast feeding for 6 months should be increased because the number of occurrence of acute diarrhea in infants age $0-1$ years at Kuranji Padang city Clinics. Research conducted by Wijayanti (2010)on 60 infants ages o-6 months in Surakarta obtained results there is a significantrelationship between exclusive breast feeding with the incidence of diarrhea. Significance of results $\mathrm{p}$ value $<$ 0.001.Nutritional status as the State of health of a person's body or a group of consumption, caused by the absorption and use of (utilization) nutrients the food is determined based on a certain size (Riyadi, 2005).

According to Soekiman in matter of national food and Nutrition Action (Health RI, 2000), factors that affect the nutritional status of the child, among others, are infectious diseases, feeding patterns, practice hygiene and environmental sanitation, as well as the care of sick children. Nutrient consumption cannot be filled due to internal or external factors. External factor concerns the economic limitations of the family, while the internal factors are factors that are present in children who have psychological problems eat on emerge as toddlers (Suhardjo, 2002).

Nutritional status of infants has a role in the event of illness. A study carried out in Peruvian showed a relationship between nutritional status with the incidence of diarrhea in infants. In this research indicates the frequency of diarrhea decreased $15 \%$ increase every z-score (Checkley et al., 2001). Recent research conducted in Klaten showed the same results, namely nutriational status has a significant relationship with the occurrence of diarrhea which is not a good nutritional status will be prone to incidents of diarrhea.

This is in accordance with the research conducted by Astya et al., (2009) obtained as a result there is a significant relationship between the nutritional status with diarrhea with value $(\mathrm{p}<0.05)$, that there is a significant relationship between nutritional status and diarrhea. This means that children with poor nutritional status will likely suffer more diarrhea. Research conducted by Dewi (2011) Bali obtainedthe result that there is a significant relationship between the nutritional status with the incidence of diarrhoea (OR: 5.46 ; 3.039.84) which means the baby with nutritionhave less risk of diarrhea 5.46 times greater compared to good nutrition.

Cleanliness of facility's individual or individuals is an act to maintain the cleanliness of one's health and to physical and psychological well-being (Tarwoto and Wartonah, 2011). Personal hygiene must be observed because the hygiene will affect health and psychological state of a person, it is strongly influenced by individual values and custom (Tarwoto, 2006). 
Bad hygiene can facilitate the transmission of diarrhea either through food, drinking water is mixed up germs cause diarrhea. In addition individual hygiene is also capable of causing the onset of diarrhea. Diarrhea prevention efforts can be prevented through handwashing using clean water.

\section{REFERENCE}

Adiasasmito W (2007). Faktor Risiko Diare Pada Bayi dan Balita di Indonesia: Systematic Review PenelitianAkademik Bidang Kesehatan Masyarakat. Makara Kesehatan, 11(1): 1-10.

Agus S, Handoyo, Widiyanti (2009). Analisis Faktor-FaktorRisiko yang Mempengaruhi Kejadian Diare pada Balita di Puskesmas Ambal 1 Kecamatan Ambal, Kabupaten Kebumen. Jurnal Ilmiah Kesehatan Keperawatan UNSOED, 5(2).

Allen IH (2012). B Vitamins in BREAST FEEDING: Relative Importance of Maternal Status and Intake, and Effects on Infant Status and Function. An International Review Journal, 3: 362-369.

Amaliah (2010). Hubungan Sanitasi Lingkungan Dan Faktor Budaya Dengan Kejadian Diare Pada Anak Balita Di Desa Toriyo Kecamatan Bendosari Kabupaten Sukoharjo. Prosiding Seminar Nasional Unimus. Fakultas Kedokteran Universitas Muhammadiyah Semarang: Semarang.

Anorital, Andayasari L (2011). Kajian Epidemiologi Penyakit Infeksi Saluran Pencernaan yang Disebabkan Oleh Amoeba di Indonesia. Artikel. Media Litbang Kesehatan, 21(1): 1-9.

Bahiyatun (2009). Buku Ajar Asuhan Kebidanan Nifas Normal. Jakarta: EGC.
Dinas Kesehatan Kabupaten Purbalingga (2014). Profil Kesehatan Kabupaten Purbalingga. Purbalingga: Dinas Kesehatan Kabupaten Purbalingga.

Dinas Kesehatan Provinsi Jawa Tengah (2014). Profil Kesehatan Provinsi Jawa Tengah. Semarang: Dinas Kesehatan Provinsi Jawa Tengah. (2014). Faktor-Faktor yang Berhubungan dengan Kejadian Diare pada Balita yang Berobat ke Badan Rumah Sakit Umum Tabanan. Jurnal Kesehatan Lingkungan, 4(2): 134-139.

Fajar AN, Misnaniarti (2011). Hubungan Pengetahuan dan Sikap Terhadap Perilaku Cuci Tangan Pakai Sabun Pada Masyarakat di Desa Senuro Timur. Jurnal Pembangunan Manusia, 5(1).

Hanif, Mulyani NS, Kuscithawati S (2011). Faktor Risiko Diare Akut pada Balita. Berita Kedokteran Masyarakat, 27(1): 10-17.

Karyono, Basirun, Septiwi (2009). FaktorFaktor Yang Mempengaruhi Kejadian Pasien Diare Pada Anak Di RSUD Majenang Kabupaten Cilacap. Jurnal Ilmiah Kesehatan Keperawatan, 5(1): 57-63.

Kementerian Kesehatan RI (2015). Profil Kesehatan Indonesia Tahun 2014. Jakarta: Kementerian Kesehatan Republik Indonesia.

Latan (2014). Aplikasi Analisis Data Statistik Untuk Ilmu Sosial Sain dengan IBM SPSS. Bandung: Alfabeta.

Mafazah (2013). Ketersediaan Sanitasi Dasar, Personal Hygiene Ibu dan KejadianDiare. JurnalKesehatanMasyarakat, 8(2): 176-182.

Mengistic B, Berhane Y, Worku A (2013). Prevalence of Diarrhea and Associated Risk Factors Among Children Under-five Years of Age in Eastern Ethiopia: A Cross-sectional Study. 
Open Journal of Preventive Medicine, 3(7): $1-8$.

Murti B (2010). Desain dan Ukuran Sampel untuk Penelitian Kuantitatif dan Kualitatif di Bidang Kesehatan. Edisi ke 2. Yogyakarta. Gadjah Mada University Press.

Murti (2013). Desain dan Ukuran Sampel untuk Penelitian Kuantitatif dan Kualitatif di Bidang Kesehatan.Yogyakarta. Edisi ke 3. Gadjah Mada University Press.

Proverawati R (2012). Perilaku Hidup Bersih dan Sehat (PHBS). Yogyakarta: NuhaMedika.

Palupi A, Hadi H, Soenarto (2009). Status Gizi Dan Hubungannya Dengan Kejadian Diare Pada Anak Diare Akut DiRuang Rawat Inap RSUP Dr. Sardjito Yogyakarta. Jurnal Gizi Anak Indonesia. 6(1): 1-9.

Ramadhani E, Lubis G, Edison (2013). Hubungan Pemberian ASI Eksklusif dengan Angka Kejadian Diare Akut pada Bayi Usia 0-1 Tahun di Puskesmas Keranji Kota Padang. Jurnal Kesehatan Andalas. 2(2):62.

Riset Kesehatan Dasar Indonesia (2013). Badan Penelitian dan Pengembangan Kesehatan Republik Indonesia. Jakarta.

Riset Kesehatan Dasar Jateng (2013). Riset Kesehatan Dasar Provinsi Jawa Tengah Tahun 2013. Semarang.

Rochimah (2009). Evaluasi Pelaksanaan Kampanye Sosial Perilaku Hidup
Bersih dan sehat Untuk Menurunkan Angka Diare di Kabupaten Kulonprogo. Jurnal Komunikasi,6(1).

Sander MA (2005). Hubungan factor Sosio Budaya dengan Kejadian Diare di Desa Candinegoro Kecamatan WonoayuSidoarjo. JurnalMedika, 2(2):163139.

Setiadi EM (2006). Ilmu Sosial dan Budaya Dasar. Jakarta: Kencana.

Taniuchi M, Sobuz SU, Begum S, PlattsMills JA, Liu J (2013).Etiology of Diarrhea in Bangladesh Infant in the First Year of Life Using Molecular Methods. Journal of Infectious Disease, 208(11):1794-1802.

Tambuwun, Ismanto, Silolonga (2015). Hubungan Sanitasi Lingkungan Dengan Kejadian Diare Pada Anak Usia Sekolah Di Wilayah Kerja Puskesmas Bahu Manado. e-Journal keperawatan (e-Kp), 3(2).

Tondare MB, Raje VV, Ganganahalli P, Mumbare S, Rayate MV (2014). Effect of Hand Washing Practice \& Attack Rate of Acute Diarrhoeal Diseases among Pre-Primary School Children. International Journal of Health Sciences and Research, 4(9):31-36.

Unit Pelaksana Teknis Daerah Puskesmas Karanganyar (2015). Profil Kesehatan PuskesmasKaranganyar 2015.

WHO (2005). The Treatment of Diarrhoea. A Manual for Physicians and Other Senior Health Workers. Geneva. 